\title{
The Bladon Lysimeter: An Innovative Environmental Characterization Technology
}

November 14, 2000

Carol A. Eddy-Dilek

Environmental Restoration Technologies Section

Savannah River Technology Center

Authentication
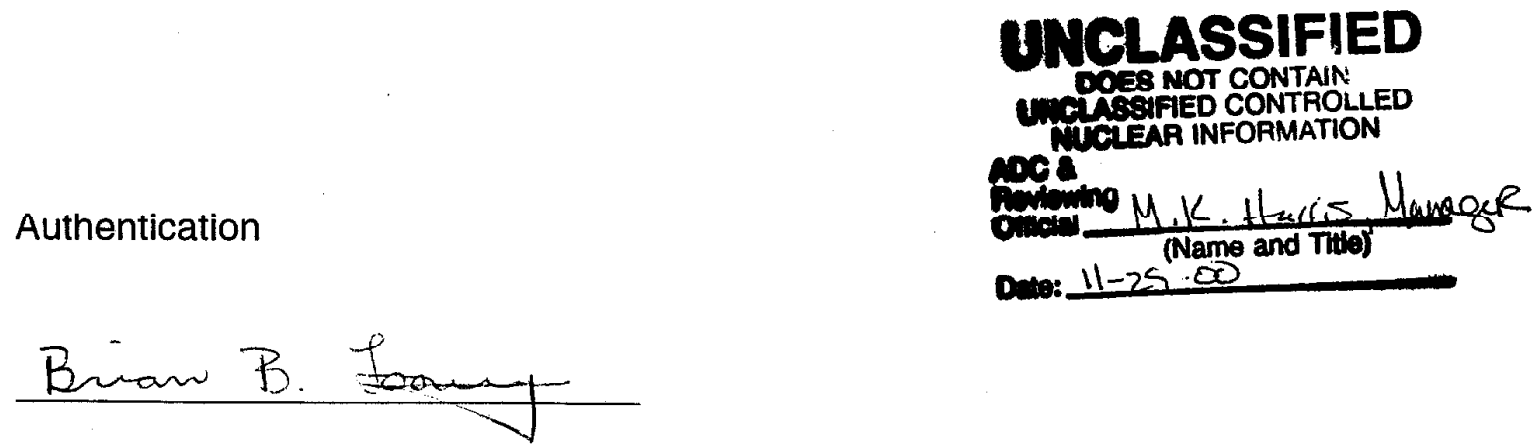

Westinghouse Savannah River Company

Savannah River Site

Aiken, South Carolina 29808

Prepared for the United States Department of Energy under Contract No. DE-AC09-96SR18500 
This document was prepared in conjunction with work accomplished under Contract No.

DE-AC09-96SR18500 with the U.S. Department of Energy.

\section{DISCLAIMER}

This report was prepared as an account of work sponsored by an agency of the United States Government. Neither the United States Government nor any agency thereof, nor any of their employees, makes any warranty, express or implied, or assumes any legal liability or responsibility for the accuracy, completeness, or usefulness of any information, apparatus, product or process disclosed, or represents that its use would not infringe privately owned rights. Reference herein to any specific commercial product, process or service by trade name, trademark, manufacturer, or otherwise does not necessarily constitute or imply its endorsement, recommendation, or favoring by the United States Government or any agency

thereof. The views and opinions of authors expressed herein do not necessarily state or reflect those of the United States Government or any agency thereof.

This report has been reproduced directly from the best available copy.

Available for sale to the public, in paper, from: U.S. Department of Commerce, National Technical Information Service, 5285 Port Royal Road, Springfield, VA 22161, phone: (800)

553-6847, fax: (703) 605-6900, email: orders@ntis.fedworld.gov online ordering: http://www.ntis.gov/ordering.htm

Available electronically at http://www.doe.gov/bridge

Available for a processing fee to U.S. Department of Energy and its contractors, in paper, from: U.S. Department of Energy, Office of Scientific and Technical Information, P.O. Box 62, Oak Ridge, TN 37831-0062, phone: (865 ) 576-8401, fax: (865) 576-5728, email: reports@ adonis.osti.gov 


\section{SECTION 1}

\section{SUMMARY}

\section{Technology Summary}

\section{Problem:}

Chemical analysis of groundwater samples is the baseline method of characterizing and monitoring groundwater contamination in the vadose (unsaturated) zone at most waste sites. Contamination moving from the surface to the water table passes through an unsaturated zone that can range in thickness from a few inches to hundreds of feet at a given site. Moisture in the unsaturated zone is retained in the pore space under surface tension and will not flow into a borehole or groundwater well under gravitational forces alone. Groundwater monitoring wells cannot be used to collect groundwater for sampling and analysis in the unsaturated zone.

How it works:

Lysimeters are samplers that are designed to apply suction to the subsurface and are typically used to collect groundwater in the unsaturated zone. Simply, a lysimeter is a porous cup that is located on the end of a hollow tube. Applying suction to the end of the hollow tube collects the water sample. When the suction is greater that the soil moisture tension in the soil, soil water will be drawn into the porous cup. Installation of a standard lysimeter into a borehole requires tedious and complicated procedures.

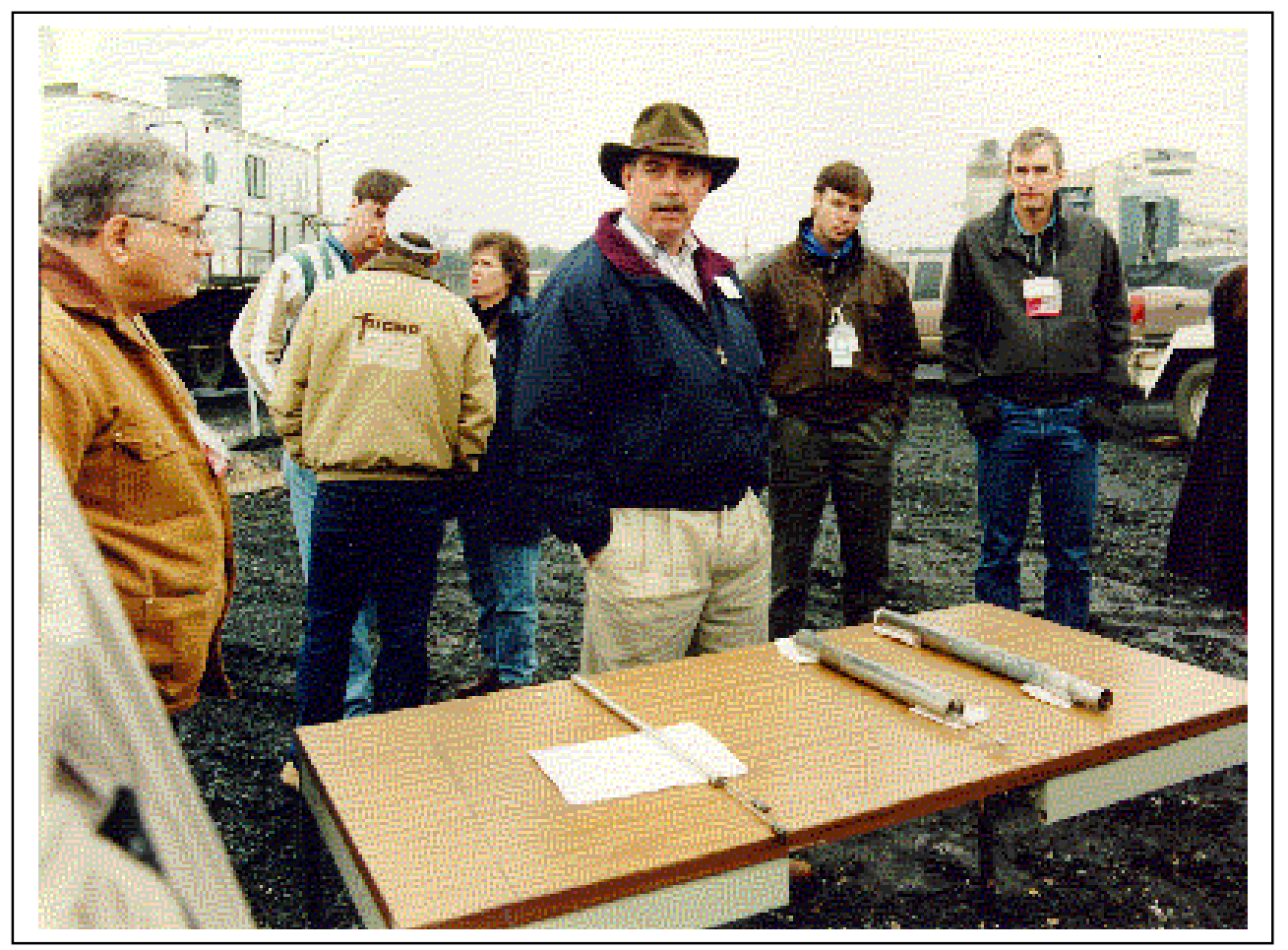

Figure 1. This photograph was taken during Visitor's Day for the Bladon Lysimeter. The sample transfer vessel is shown to the left on the table and the lysimeter unit is shown to the right.

The Bladon Lysimeter is a lysimeter designed for use with a cone penetrometer (CPT) truck or other type of direct-push system. The body and extraction tube of the lysimeter are constructed with stainless steel and are the same diameter as a CPT rod. The groundwater is drawn into the sampling chamber through a porous nickel filter. The lysimeter probe is advanced to the desired depth with the cone penetrometer, and the lysimeter is left in place. A vacuum induced at the surface is used to draw water into the 
lysimeter, and a valve is closed. A pressure line is then used to bring the sample to the surface. Samples have been successfully obtained from depths up to 95 feet.

Potential Markets:

Monitoring of the vadose zone beneath hazardous waste land-treatment systems is required under Subtitle $\mathrm{C}$ of the Resource Conservation and Recovery Act (RCRA). States may also require vadose zone monitoring beneath other types of hazardous waste facilities. Most of the DOE sites are known to have vadose groundwater contamination concerns. This lysimeter technology is most applicable to waste sites with relatively unsaturated zones where the contamination is located at depths of less than 90 feet.

The baseline method for collection of vadose zone soil moisture is installation of standard ceramic lysimeters. The Bladon Lysimeter provides several advantages over the baseline method:

- Use of the Bladon Lysimeter significantly increases the speed and decreases the cost of installation.

- The use of direct-push methods for installation of the Bladon Lysimeter minimizes secondary hazardous waste brought to the surface.

- Because the Bladon Lysimeter is ready to operate immediately upon emplacement, it can be used to rapidly characterize a waste site.

- The cost analysis shows that the Bladon Lysimeter saves an estimated $6 \%$ over the baseline technology for permanent installations and 34\% for temporary installations.

\section{Demonstration Summary}

The Bladon Lysimeter was evaluated as part of the Rapid Commercialization Initiative (RCI) during 1997 at three separate locations on the Savannah River Site (SRS). Specific objectives of the RCI included:

- To provide assistance in identifying appropriate technology demonstration sites.

- To provide assistance in technology performance verification activities.

- To provide assistance in meeting technology demonstration permitting requirements while simultaneously facilitating multistage participation in the demonstration.

This document summarizes the evaluation and testing of the Bladon Lysimeter through May 1998. The goals of the evaluation were to assess the effectiveness and time required to obtain water samples in the saturated and unsaturated zones from various soil types and to compare the chemical analyses of the samples collected with the Bladon Lysimeter with those collected using a standard ceramic lysimeter. The results showed that:

- Installation of the Bladon Lysimeter by direct-push technology is quicker and easier than installation of ceramic lysimeters by traditional drilling methods. Direct-push and cone penetrometer technology also significantly reduces the amount of secondary waste produced during the installation and removal of the lysimeter.

- Pore water samples were successfully collected by the Bladon Lysimeter from a variety of soil types from depths up to 83 feet during this demonstration. In most cases, the Bladon Lysimeter obtained an adequate volume of sample for most chemical analyses in a matter of several hours in the vadose zone.

- The chemical results of water samples collected with the Bladon lysimeter were compared with samples collected from standard lysimeters. Although both the baseline and Bladon lysimeters were sampled over a 3 month period, concentrations of key analytes in a given location over time were erratic and often showed decreasing trends. 


\section{Technical}

Joseph Scroppo, Bladon International, Inc., 630-574-3965

Candace Rose, Argonne National Laboratory, 630-252-3499, candace_rose@qmgate.anl.gov

\section{Management}

Joseph Ginanni U.S. Department of Energy, 702-295-0209, ginanni@nv.doe.gov

Charles Nalezny, U.S. Department of Energy, 301-903-1742, charles.nalezny@em.doe.gov

\section{Regulatory}

Mark Kessinger, U.S. Army Corps of Engineers, 304-529-5083, markk@mail.orh.usace.army.mil

Dr. James Divine, Washington State Department of Ecology, 509-736-5700, jamesrdivine@rl.gov

Dr. Jerry Hill, Southern States Energy Board, 770-242-7712, hill@clever.net

Mr. Eric Koglin, U.S. Environmental Protection Agency, 702-798-2261

Mr. Rich Tomlinson, Western Govenors Association, 916-920-9580, rick.tomlinson@internetmci.com

Mr. Keith Collinsworth, South Carolina Department of Health and Environmental Compliance, 803-896-4055

Mr. John Wasnousky, California Environmental Protection Agency, 916-322-2543

Mr. Mark Densmore, Illinois Environmental Protection Agency, 217-785-8725

\section{Note}

All published Innovative Technology Summary Reports are available on the U. S. Department of Energy Office of Science and Technology (OST) web site at http://em-50.em.doe.gov under "Publications." The Technology Management System, also available through the OST web site, provides information about OST programs, technologies, and problems. The OST Reference \# for the Bladon Lysimeter is 2365. 


\section{SECTION 2}

\section{TECHNOLOGY DESCRIPTION}

\section{Overall Process Definition}

Demonstration goals and objectives:

The Bladon Lysimeter was evaluated during FY 1998 as part of the Rapid Commercialization Initiative $(\mathrm{RCI})$ program at the DOE Savannah River Site (SRS). Argonne National Laboratory (ANL) personnel provided third party verification of the technology as specified by the $\mathrm{RCl}$ program. Westinghouse Savannah River Company (WSRC) personnel provided field logistical support funded by the Characterization, Monitoring, and Sensor Technology Crosscutting Program (CMST-CP). The goals of the evaluation documented in the test plan were to provide information about the use and effectiveness of the Bladon Lysimeter in collecting samples of both vadose zone water and saturated zone water (ANL 1997).

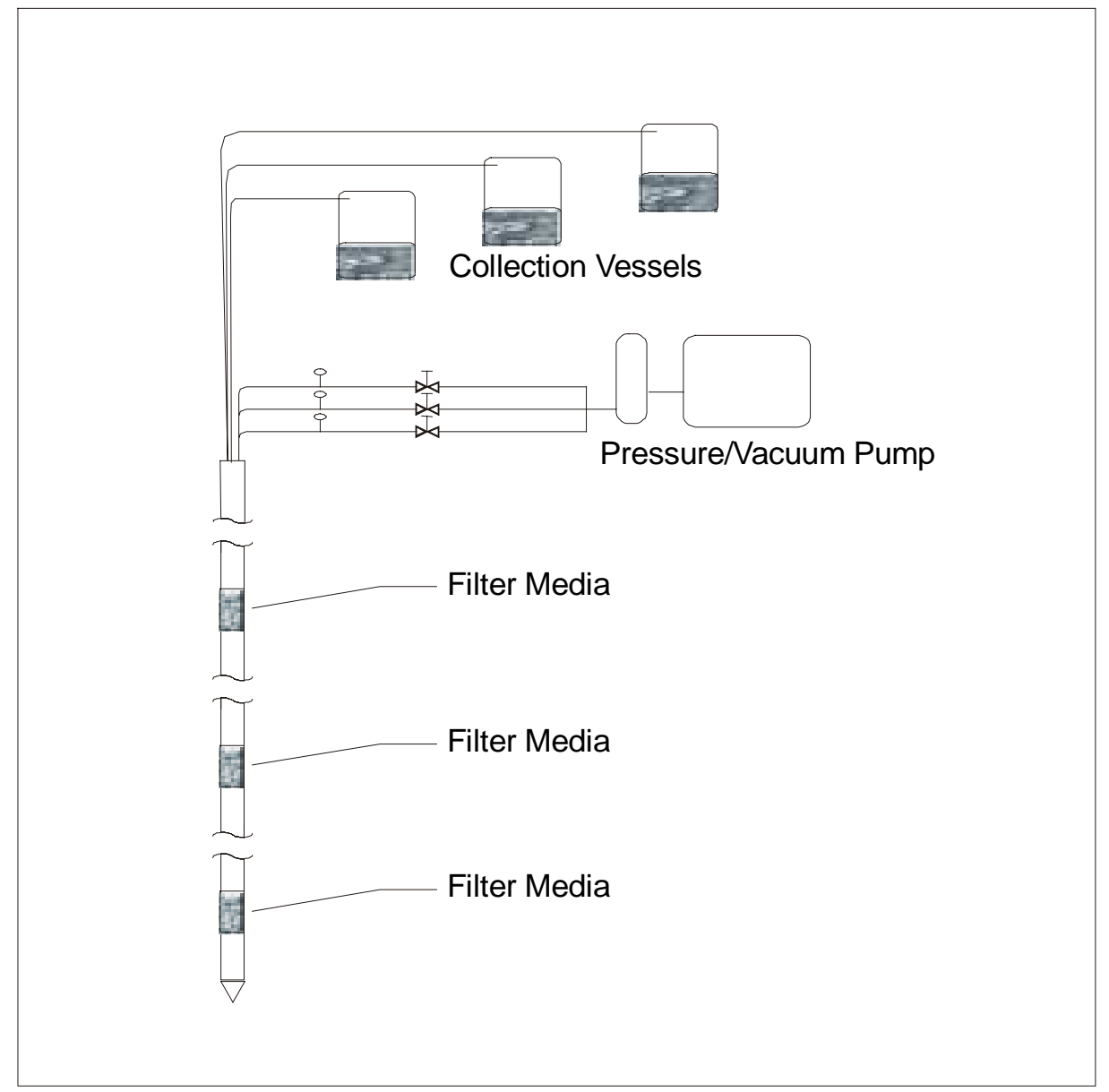

Figure 2. Schematic Diagram of the Bladon Lysimeter system showing a possible configuration with three lysimeters installed on the same Cone Penetrometer Truck probe. 
- A lysimeter is a porous cup located at the end of a hollow tube that is designed for sampling in the vadose zone. The cup is typically made of ceramic material, nylon, or stainless steel.

- A soil water sample is collected by applying suction to the end of the hollow tube. When the suction is greater than the soil moisture tension in the soil, the pressure gradient drives movement of groundwater from the soil into the porous cup. The water in the porous cup is then drawn through the tubing to the surface for collection.

- A pressure-vacuum lysimeter extends the effective sampling depth for lysimeters to depths greater than ten feet. This system uses two tubes that run to the surface. One tube is pressure vacuum line that is used to apply a vacuum to move water into the sampling cup. The sample is removed by opening the second tube, a discharge line near the bottom of the sampler, and applying pressure to the vacuum line to push the sample to the surface. The depth capability can be further extended by the addition of a sample chamber that can be isolated from the lysimeter cup. The Bladon lysimeter is a pressure-vacuum lysimeter.

Key elements of the technology:

- The Bladon lysimeter is composed of a stainless steel body, a porous nickel sampling filter, and a stainless steel extraction tube. A stainless steel ram point is designed with the same specifications as a standard CPT probe point (diameter 1.7-inch).

— The nickel filter is extremely hydrophilic (a strong affinity for water), has a porosity of $60 \%$, a narrow range in pore size and is designed to withstand 15 tons of hydraulic driving force from the cone penetrometer truck.

- The extraction tube, also constructed of stainless steel, coupled with a transfer vessel, is capable of drawing samples from depths up to 95 feet. Liquid is drawn into the transfer vessel by applying a vacuum of 20-21 inches of mercury on the extraction tube.

- The sample is pushed to the surface by application of pressure. The transfer vessel is used to extend the effective depth range of the sampler. The pressure required to push the sample to the surface from intermediate depths would drive the sample back into the formation. The pressure vessel isolates the sample from the formation so higher pressures can be used to move it to the surface.

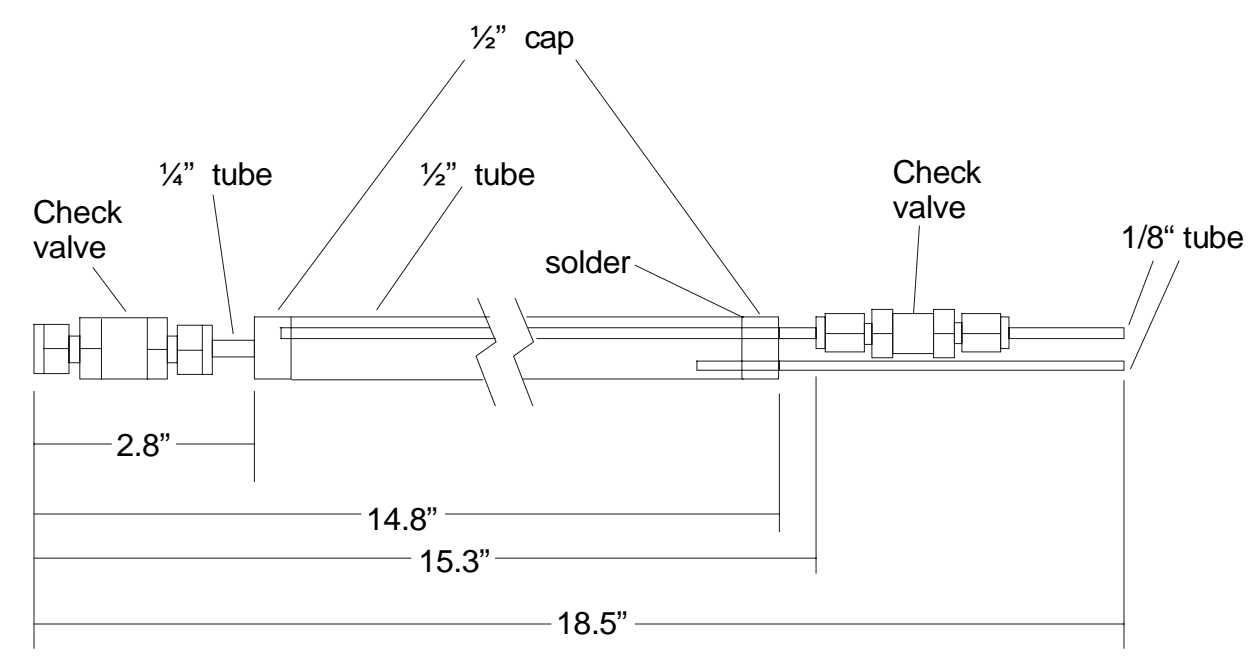

Figure 3. Schematic Diagram of the Transfer Vessel Designed for the Bladon Lysimeter 
The primary advantage of the Bladon Lysimeter over standard lysimeters results from simplified installation with the CPT.

- Standard lysimeters are installed in augured holes that have a greater diameter than the lysimeter. The lower zone of the borehole is filled with a slurry of silica flour. The cup of the lysimeter must be well embedded in the slurry to provide adequate hydraulic contact with the subsurface material. The unit must be installed and then water is allowed to drain from the slurry to determine if the lysimeter will hold a vacuum. Significant volumes of distilled water are used during the process of installation. Consequently, after installation, the lysimeter needs to be purged until consistent water quality is obtained. Typically lysimeters are allowed to 'age' at least several months before they are sampled.

- The use of a cone penetrometer installed Bladon Lysimeter eliminates the need for complicated installation procedures and eliminates the production of investigation-derived waste during drilling operations. A major advantage of the direct-push emplacement technique is that it provides immediate hydraulic contact with the formation. No purging is required. Immediately upon emplacement, Bladon Lysimeters can begin sampling. This advantage may make Bladon Lysimeters suitable for site characterization.

\section{System Operation}

The Bladon Lysimeter is deployed by direct-push technology with a cone penetrometer truck and can be used in different scenarios for sampling.

- A single lysimeter can be moved to different depths in a single borehole.

- Multiple lysimeters can be placed within in single cone penetrometer string in order to sample at multiple depths concurrently.

- A lysimeter can be used in a dynamic characterization scheme in which multiple depths are sampled in a single borehole and the lysimeter is removed.

- A lysimeter can be used for monitoring with one or more sampling filters pushed to the desired depth(s) as a temporary or long-term monitoring location(s).

Emplacement of the Bladon Lysimeter is possible in unconsolidated geologic materials at depths up to 95 feet that are penetrable by direct-push technology.

- A standard cone penetrometer truck and crew can be used to install Bladon Lysimeters.

- The use of direct-push technology eliminates secondary waste handling requirements.

- There are no inherent risks associated with use of the Bladon Lysimeter other than those generally associated with the use of direct-push technology. 


\section{Demonstration Plan}

The site evaluation of the Bladon Lysimeter was conducted at the Savannah River Site (SRS) in January and March 1998 as part of the RCl. Previously the Bladon Lysimeter had been tested in at SRS in Marea (Scroppo and Scroppo 1995). During the previous tests, the Bladon Lysimeter had successfully been used to recover groundwater samples in two hours from several soils types as deep as 90 feet. Problems were encountered with the structural integrity of the sampler, minor equipment failures, and some difficulty recovering samples.

The specific objectives of this Bladon Lysimeter evaluation included:

- Evaluate its effectiveness in obtaining water samples from subsurface zones of varying soil type, moisture content, and depth.

- Evaluate its effectiveness in obtaining water samples in a reasonable time consistent with active site characterization.

- Evaluate its effectiveness in obtaining a sufficient quantity of water to allow for standard chemical analyses $(30 \mathrm{ml})$.

- Evaluate its performance in obtaining water samples in comparison with a standard lysimeter.

- Compare the chemical analyses of samples collected with the Bladon lysimeter with those collected by using a standard ceramic lysimeter.

The Bladon Lysimeter was tested at three locations at SRS described below. Detailed description of the evaluation and analysis is provided in the evaluation report (ANL 1998). At each test location, standard lysimeters were installed first at each of the test sites. Geologic core data and soil moisture data were gathered during installation of standard ceramic lysimeters to provide information used in selecting depths for installing Bladon Lysimeters. Each Bladon Lysimeter was pre-evaluated for its bubble point and its functionality prior to installation.

- The D Area coal pile is contaminated with a variety of metals leached from a very large coal pile maintained at the $D$ Area powerhouse. Groundwater is shallow and highly acidic $(\mathrm{pH}<2)$. D Area was to serve as a testing site for the ability of the Bladon Lysimeter to collect samples from the saturated zone and for the comparison of contaminant concentrations measured with different devices. A field trial in January 1997, revealed that the low pH of groundwater at the D Area site caused degradation of the nickel frits.

- An uncontaminated location in the TNX Area was selected to evaluate the ability of the Bladon Lysimeter to obtain water samples in a variety of soils with different moisture contents because extensive geologic and soil moisture data were available for this site. Groundwater is located at depths of 35 to 50 feet below ground surface and the sediments are composed of interbedded fine sand, silt, and clay. Difficulties were encountered installing both ceramic and Bladon lysimeters at this site. Attempts to install the standard lysimeter failed due to coarse sediments. In January, a single Bladon Lysimeter was successfully installed. During other attempts at TNX, the nickel frits were cracked and gouged by coarse sediments during the installation process. Since baseline data was not collected, this site was only used to test the ability of the Bladon Lysimeter to recover water in different soil types. Samples were not analyzed from this site.

- An uncontaminated location in M Area was selected as an alternative site to the TNX Area and served as the primary testing location for comparison of water quality in samples from both types of lysimeters over extended periods of time. Sediments at M Area consist of sand, clayey sand, and 
sandy clays. Groundwater is located at depths of 120 to 140 feet below ground surface. Standard water quality parameters (magnesium, calcium, nitrate, and chloride) were measured.

\section{Results}

On the basis of this evaluation, the Bladon lysimeter did prove that it is effective in several areas.

- Installation of the Bladon Lysimeter by direct-push technology is quicker and easier than installation of ceramic lysimeters by traditional drilling methods.

- Use of direct-push technology to install Bladon Lysimeters produces essentially no drilling wastes during installation and abandonment of the lysimeters. By contrast, standard drilling practices and lysimeter development can produce significant volumes of waste.

- Soil moisture samples of adequate volume for standard chemical analyses can be collected in a matter of hours in the vadose zone and within an hour in the saturated zone.

- Soil moisture samples were successfully collected from a variety of soil types and from depths up to 83-feet.

- The chemical analyses of water samples in this evaluation were inconclusive to evaluate the quality of the water samples collected with the Bladon Lysimeter (Tables $1 \& 2$ ). Duplicate and split samples collected in the field did not show good correlation. These complications made evaluation of the effectiveness of the Bladon Lysimeter for chemical sampling impossible. Data from D Area suggests that nickel from the filter may dissolve from the sampler at sites where the groundwater is acidic.

- The samples collected from the permanent installations in M Area may possibly indicate that aging may be required for both types of lysimeters because the concentrations of most of analytes decreased each month in samples from both types of lysimeters.

- The lysimeter did not consistently withstand installation in coarse sediments such as gravel and cobbles. Scratches and gouges destroyed the nickel filter. This problem could be reduced by first pushing a hole with the standard cone penetrometer tip followed by installation of the lysimeter into the hole.

- If the nickel filter is damaged or clogged by fine-grained material during installation, its ability to draw soil moisture will be reduced or eliminated. 
Table 1. Chemical analysis results from D Area Coal Pile

\begin{tabular}{|c|c|c|c|c|c|c|c|}
\hline \multirow{2}{*}{$\begin{array}{l}\text { Sampling } \\
\text { Depth (ft) } \quad \text { Device }\end{array}$} & \multirow{2}{*}{$\begin{array}{c}\text { Sampling } \\
\text { Date }\end{array}$} & \multicolumn{5}{|c|}{ Analyte (ug/L) } & \multirow[b]{2}{*}{ Comments } \\
\hline & & $\mathrm{Al}$ & $\mathrm{Ca}$ & $\mathrm{Fe}$ & $\mathrm{Ni}$ & $\mathrm{SO}_{4}$ & \\
\hline 7.5Bladon & January & $-^{a}$ & - & - & - & $1,030,000$ & 5.68Small Sample \\
\hline 10Bladon & January & 511 & 62600 & 6650 & 178000 & 944000 & 5.45 \\
\hline 10Bladon & May & 244 & 332000 & 335000 & 20100 & $N A^{b}$ & 3.52Rusty red sample \\
\hline 10Bladon & June & - & - & - & - & - & - \\
\hline 10Bladon & July & - & - & - & - & - & - \\
\hline 10Ceramic & March & 124000 & 276000 & 142000 & 2410 & 3510000 & 4.01 \\
\hline 10Ceramic & May & 250000 & 212000 & 83500 & 2240 & NA & 3.82 \\
\hline 10Ceramic & June & NA & NA & NA & NA & 680000 & 3.72 \\
\hline 10Ceramic & July & NA & NA & NA & NA & 10300000 & 3.64 \\
\hline 16.5Bladon & January & 345 & 114000 & 25400 & 184000 & 2270000 & 7.42 \\
\hline 16.5Bladon & January & 231 & 79300 & 38200 & 78000 & 964000 & 5.7Duplicate \\
\hline 16-17Bailer & January & 280000 & 70400 & 225000 & 7100 & 916000 & 4.83 \\
\hline 16-17Bailer & January & 522000 & 84500 & 387000 & 7130 & 929000 & 3.91 Duplicate \\
\hline 16-17Bailer & January & 187000 & 148000 & 309000 & 14600 & 928000 & 4.17Split \\
\hline
\end{tabular}

Table 2. Chemical analysis results from M Area

\begin{tabular}{|c|c|c|c|c|c|c|c|}
\hline \multirow[b]{2}{*}{ Depth (ft) } & \multirow[b]{2}{*}{$\begin{array}{l}\text { Sampling } \\
\text { Device }\end{array}$} & \multirow[b]{2}{*}{$\begin{array}{c}\text { Sampling } \\
\text { Date }\end{array}$} & \multicolumn{4}{|c|}{ Analyte (ug/L) } & \multirow[b]{2}{*}{ Comments } \\
\hline & & & $\mathrm{Ca}$ & $\mathrm{Mg}$ & $\mathrm{Cl}$ & $\mathrm{NO3}$ & \\
\hline 26.5 & Bladon & March & 14000 & 4760 & 23500 & & \\
\hline 26.5 & Bladon & May & 6600 & 1620 & 94 & & \\
\hline 26.5 & Bladon & June & 1480 & 1480 & 328 & & \\
\hline 26.5 & Bladon & July & 1250 & 1250 & 2230 & & \\
\hline 27.5 & Ceramic & March & 44800 & 4430 & 12000 & & \\
\hline 27.5 & Ceramic & May & 7740 & 2270 & 184 & & \\
\hline 27.5 & Ceramic & June & 3700 & 1710 & 1650 & & \\
\hline 27.5 & Ceramic & July & 2400 & 1560 & 2730 & & \\
\hline 36.5 & Bladon & January & 14000 & 6300 & 949 & & \\
\hline 36.5 & Bladon & January & 8330 & 2870 & $-a$ & & - \\
\hline 36.5 & Bladon & March & 5040 & 1490 & 1740 & & \\
\hline 36.5 & Bladon & May & 2230 & 919 & 621 & & \\
\hline 36.5 & Bladon & June & 2330 & 1200 & 302 & & \\
\hline 36.5 & Bladon & July & 2150 & 1130 & 546 & & \\
\hline 34.5 & Ceramic & January & 22900 & 2970 & 1270 & & \\
\hline 34.5 & Ceramic & March & 22500 & 3470 & 11800 & & \\
\hline 34.5 & Ceramic & March & 27500 & 4150 & 2510 & & 9Split \\
\hline 34.5 & Ceramic & May & 11400 & 2040 & 72 & & \\
\hline 34.5 & Ceramic & May & 11700 & 2040 & 47 & & 0Duplicate \\
\hline 34.5 & Ceramic & June & 10100 & 1950 & 206 & & \\
\hline 34.5 & Ceramic & July & 6140 & 1620 & 4300 & & \\
\hline
\end{tabular}

a No sample 


\section{TECHNOLOGY ALTERNATIVES AND APPLICABILITY}

\section{Competing Technologies}

The standard method for collection of soil water in the unsaturated zone is with a suction or pressurevacuum lysimeter. Standard lysimeters have the following limitations (ANL, 1998):

- Lysimeters are installed into an augured hole that has a greater diameter that the lysimeter. The lower zone of the borehole is filled with a slurry of silica flour. The cup of the lysimeter must be well embedded in the slurry to provide adequate hydraulic contact with the subsurface material. The lysimeter must be installed several months before samples are collected to allow the water used during the installation to be removed.

- Many types of porous segments are available with various specifications. Materials with larger pore sizes are stronger but limit the vacuum that can be applied before the bubble pressure is exceeded.

- Standard lysimeters have difficulty in collecting samples over a wide range of soils and depths.

- Installation of standard lysimeters is complex and time consuming.

- Investigation-derived waste is produced during drilling. In addition, since a significant amount of distilled water is used during the process of installation of the baseline lysimeter, the lysimeter needs to be purged until consistent water quality is obtained. This purge water is typically treated as a hazardous waste.

- Serious technical debate regarding the representativeness of chemical concentrations measured on samples collected with suction lysimeters. Wilson et al. (1995) indicate that chemical samples from lysimeters are not representative of pore waters because only some of the soil moisture can be drawn into the sampler. Some of the water is bound in the pore space and cannot be pulled into the lysimeter. This applies to standard lysimeters as well as Bladon lysimeters.

The use of the Bladon lysimeter provides several advantages over baseline methods

- Use of the Bladon Lysimeter significantly increases the speed and decreases the cost of lysimeter installation.

- The use of direct push methods for installation of the Bladon significantly virtually eliminates elaborate installation procedures and the production of secondary hazardous waste.

- The Bladon lysimeter can be installed at deeper depths more easily than a standard lysimeter.

- Because the Bladon lysimeter can be used immediately upon emplacement, it might extend the applicability of lysimeters from waste site monitoring to waste site characterization. This application would require further testing of the lysimeter to see if 'ageing' of the Bladon lysimeter is required to collect representative samples. Sample collected over time during the test showed decreasing values for most components.

\section{Technology Applicability}

The Bladon Lysimeter is applicable to sites where standard lysimeters have been used. A common example would be monitoring groundwater flow paths away from landfills. In this example, the chemical analyses are used to indicate the presence of a given contaminant not the quantity.

The technology is applicable at sites where collection of samples from the unsaturated zone is necessary and the site is appropriate for investigation with a direct-push technology. Other samplers are available for sampling below the water table and have been demonstrated to provide representative samples for chemical analysis. Maximum sampling depths are approximately 90 to 100 feet. 


\section{Patents/Commercialization/Sponsor}

The Bladon Lysimeter is currently available for purchase from Bladon International, Inc., 25 Sheffield Lane, Oak Brook, IL 60521. 


\section{SECTION 5}

\section{COST}

\section{Introduction}

This cost analysis was prepared as part of the $\mathrm{RCl}$ program by the Army Corps of Engineers using scenarios and costs derived from the demonstration at SRS in 1997 and presented in the evaluation report of the Bladon Lysimeter (ANL 1998).

\section{Methodology}

The analysis describes the cost of the equipment, installation of the Bladon Lysimeter, and provides a comparison with the baseline technology (porous ceramic cup lysimeters). The cost analysis considers use of the lysimeter in a monitoring mode, that is, permanent installation, as well as in a characterization or 'temporary' installation. The permanent installation scenario assumes that the cone penetrometer rods are sacrificed and left in place. The cost estimates are based on installation of 14 lysimeters at eight locations (several locations have multiple lysimeters). The analysis shows that the Bladon Lysimeter saves an estimated $6 \%$ over the baseline technology for permanent installations and $34 \%$ for temporary installations.

\section{Cost Analysis}

Installation of the Bladon lysimeter requires purchase of the material from Bladon, International and the use of a Cone Penetrometer Truck (CPT) for the installation. The Bladon Lysimeter is currently available from the vendor in the configurations and costs indicated in the following table:

Table 1 - Innovative Technology Acquisition Costs

\begin{tabular}{|l|r|r|}
\hline \multicolumn{1}{|c|}{ ACQUISITION ITEM } & \multicolumn{1}{|c|}{ ITEM } & COST \\
\hline Bladon Lysimeter Purchase & Lysimeter with Filter & $\$ 1,200$ \\
& Stainless Steel Transfer Vessel & $\$ 200$ \\
& Sample Collection Indicator & $\$ 150$ \\
& Filter Replacement & $\$ 200$ \\
\hline CPT Equipment Rates & CPT Equipment \& Crew & $\$ 2,650 /$ day \\
& Decontamination Unit & $\$ 175 /$ day \\
& Grouting Hole & $\$ 1.75 /$ foot \\
\hline
\end{tabular}

The rates do not include mobilization of the CPT equipment to the site or shipping of the lysimeter.

The analysis assumes installation of fourteen lysimeters at eight different locations. This permanent installation scenario assumes that sampling would be performed after all of the lysimeters had been installed. In the case of the temporary installation, it is assumed that the sample collection is performed after the CPT moves to the next location (does not detain the installation work) and is completed prior to completing installation of the last lysimeter (does not detain removal operations). Specifically, samplers are installed, the CPT moved, the rods and samplers left temporarily in place and sampled, and then the CPT returns to that location after the sampling is completed. The sampling procedure for the Bladon Lysimeter is assumed to be the same as for the baseline case (i.e. there is no cost savings for one over the other). Other scenarios are possible and would have different costs. The temporary installation allows sampling and then removal of the lysimeter and avoids the capital costs for the lysimeters and rods.

Since permanent installation of the lysimeter requires leaving the CPT rod in the ground, it adds approximately $\$ 100$ per meter of lysimeter depth to the cost. If the installation is temporary, rather than permanent, the rods and the lysimeter can be reused a number of times depending upon the site conditions. The filter portion can be replaced in the event of damage. 
Average production rates for installation of a borehole followed by a push to install the lysimeter in the borehole were based upon recorded duration for the installation of six lysimeters in March 1997. Also, production rates observed for one installation in January were used as the basis for this estimate for the leak test, threading the cables through the rods, sampling, etc. The baseline costs were not based on observations of specific work, but were derived from historic average costs for well installations at the Savannah River Operations Office.

\section{Cost Conclusions}

The costs are compared at a summary level for the Bladon Lysimeter and the baseline in Figure 4. A detailed breakout of the costs is shown in Appendix B.

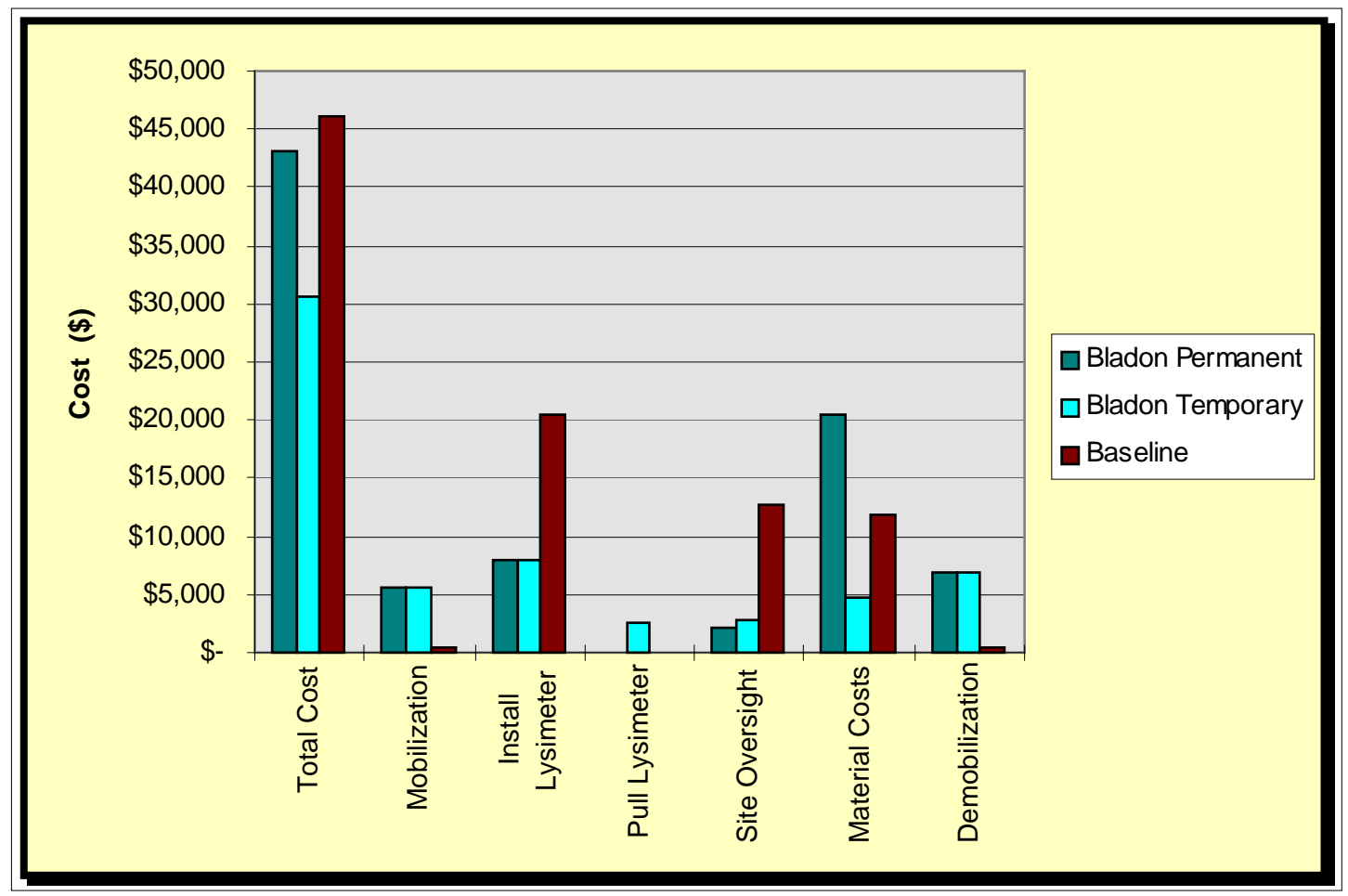

Figure 4. Cost Comparison for Three Different Scenarios

The estimated average costs for lysimeter installations (with average depth of approximately 20 feet) is $\$ 2,200$ (permanent) and $\$ 1,300$ (temporary) for Bladon and $\$ 3,200$ for the baseline, omitting mobilization costs (costs computed from Install Lysimeter subtotals shown in Appendix B by 14 lysimeters). The labor costs for the Bladon Lysimeter are substantially lower than those for the baseline because of the much higher production rates for CPT installation. On the other hand, material costs are significantly higher for the Bladon Lysimeter due to the costs of the added CPT rod. In situations where the installation was temporary, the material costs for the Bladon Lysimeter would be minimal, but labor costs for sample collection would be difficult to predict (high labor costs if the CPT truck waits during sampling and low labor costs if the CPT truck moves off to the next location). A substantial portion of the cost difference results from the larger mobilization costs for the Bladon Lysimeter (longer mobilization distance of 190 miles for the CPT truck as compared with the local drilling contractor). The significance of the mobilization costs will vary with the job size, with less impact to large jobs and more impact to small jobs. Based on the demonstration, the Bladon Lysimeter is less expensive because of its use of the CPT for installation and because it can accommodate temporary installation. 


\section{REGULATORY AND POLICY ISSUES}

\section{Regulatory Considerations}

Since this project was completed as part of the Rapid Commercialization Initiative $(\mathrm{RCl})$, representatives from several states (California, Washington, South Carolina, and Illinois) were involved in the technology evaluation and verified the performance data on the ability of the sampler to collect soil water. Contact numbers are provided in Section 1.

No special permits are required for the operation of a cone penetrometer. Permitting for installation of the Bladon lysimeters should be less stringent than those for standard lysimeters installed with drill rigs since investigation derived wastes are minimized through the use of direct-push technology. Normal procedures require that wastes should be handled according to the Resource Conservation and Recovery Act $(\mathrm{RCRA})$ regulations.

Occupational Safety and Health Administration (OSHA) requirements should be similar or less stringent than those required in standard drilling operations since workers are exposed to less noise and waste.

\section{Safety, Risks, Benefits, and Community Reaction}

\section{Worker Safety:}

The use of the Bladon Lysimeter significantly reduces the risk of radiation or chemical exposure to workers because direct-push methods are used instead of drilling.

- Secondary waste that must be handled and treated is virtually eliminated.

- Crew exposure is minimized because rods are steam cleaned before they are drawn into the compartment where the crew is located.

- Workers collect data in more rapid manner thereby reducing the length of exposure to hazardous materials.

\section{Community Safety:}

The use of the Bladon Lysimeter will not significantly impact community safety.

\section{Environmental Impact:}

The use of the Bladon Lysimeter will significantly reduce the environmental impact.

- Drill cuttings and fluids or secondary waste is virtually eliminated.

- The penetrometer holes are smaller in diameter and can be sealed during retraction of the rods.

- The lysimeter system can be easily decontaminated at the surface with a small volume of fluid.

\section{Socioeconomic Impacts and Community Reaction:}

The use of the Bladon Lysimeter will not have any socioeconomic impacts. Community reaction should be positive due to the use of an environmentally friendly technology. 


\section{SECTION 7}

\section{LESSONS LEARNED}

\section{Implementation Considerations}

- In geologic conditions where coarse-grained material is present, installing the Bladon Lysimeter in a previously pushed borehole may significantly reduce damage to the sampler.

- Lysimeters may not be appropriate for quantitative sampling of selected analytes at selected sites. For example, lysimeters are not appropriate for quantitative sampling of volatile contamination because samples collected under a vacuum will not be representative of subsurface conditions.

- Careful consideration must be given to the appropriateness of the sampling with the nickel filter; for example, high pH soil conditions are typical of sites with high levels of metal contamination.

- The site manager must work with regulators to assure acceptance of the data collected. Additional studies may be required to assess the quality of samples collected for chemical analysis.

\section{Technology Limitations and Needs for Future Development}

- Use of the Bladon lysimeter is dependent on the ability of the cone penetrometer to reach the desired depths. Sampling is restricted to depths of less than ninety-five feet.

\section{Technology Selection Considerations}

- The success of direct-push technology to deploy the Bladon Lysimeter is dependent upon the geologic conditions; for example, the Bladon lysimeter may not be appropriate in sediments with abundant cobbles or coarse grained sand. 



\section{APPENDIX A}

\section{REFERENCES}

Argonne National Laboratory, 1998, Evaluation Report for the Bladon International, Inc., Multisampling Lysimeter, Argonne National Laboratory Internal Report, Argonne, Illinois, May.

Argonne National Laboratory, 1997, Bladon International, Inc., Lysimeter Test Plan, Argonne National Laboratory Internal Report, Argonne, Illinois, January.

Scroppo, J, and G.L. Scroppo, 1995, Manufacture and Demonstration of a Vadose Zone In Situ Sample Retrieval (VSIR) System, work performed for Westinghouse Savannah River Company under Subcontract No. AB53051N, Bladon International, Inc., Oak Brook, Illinois, August.

Wilson, L.G., et al., 1995, "In Situ Pore-Liquid Sampling in the Vadose Zone," in Handbook of Vadose Zone Characterization and Monitoring, L.G. Wilson, et al. (editors), Lewis Publishers, Boca Raton, Florida, pp. 477-521. 


\section{APPENDIX B}

\section{COST ANALYSIS TABLES}

Table B1. Cost Analysis for Bladon Lysimeter Permanent Installation.

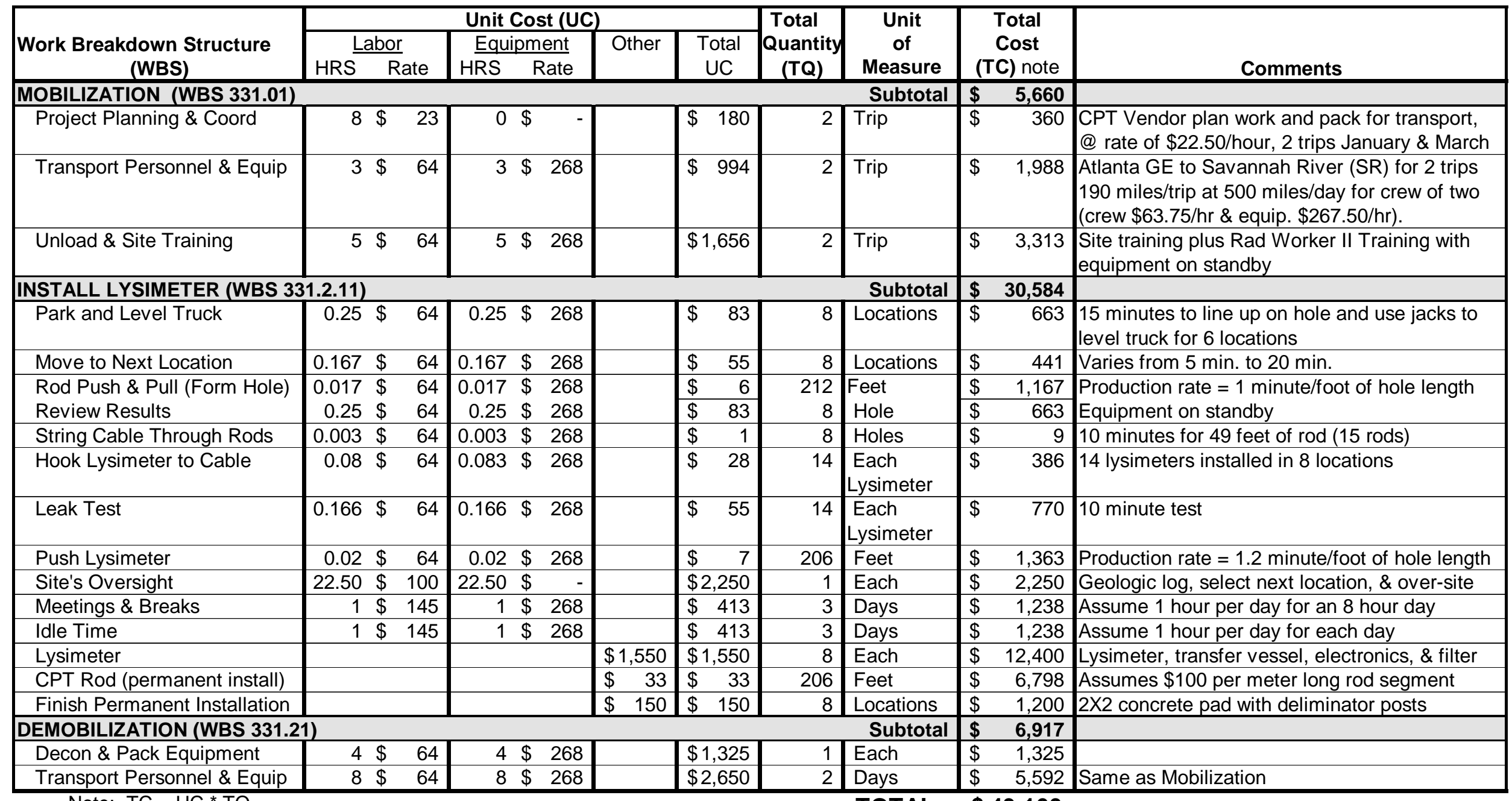

$$
\text { Note: } \mathrm{TC}=\mathrm{UC}^{*} \mathrm{TQ}
$$

TOTAL:

$\$ 43,160$ 
Table B2. Cost Analysis for Bladon Lysimeter Temporary Installation

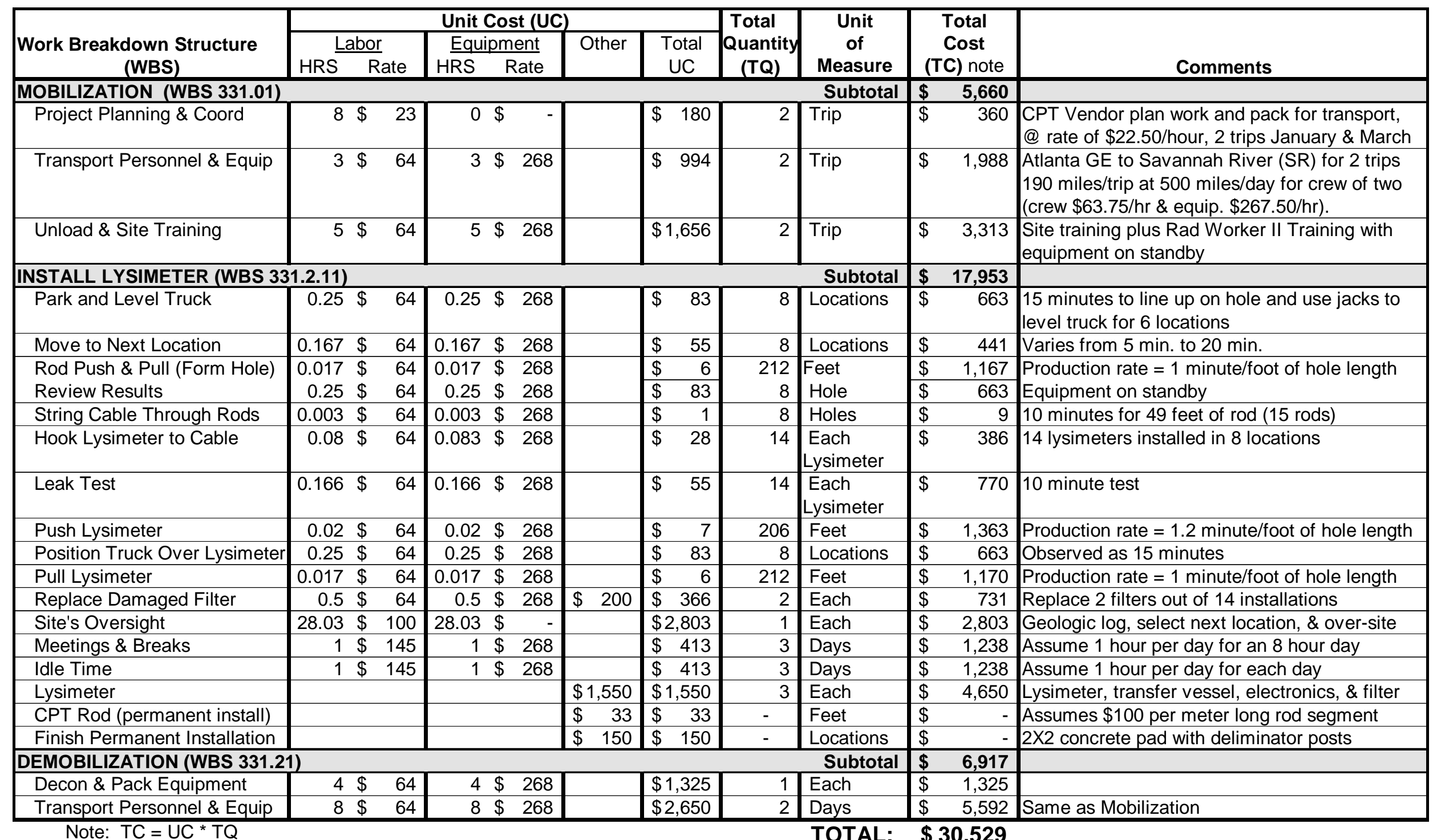

Note: $\mathrm{TC}=\mathrm{UC}^{*} \mathrm{TQ}$

TOTAL: $\quad \$ 30,529$ 
Table B3 . Cost Analysis for Baseline

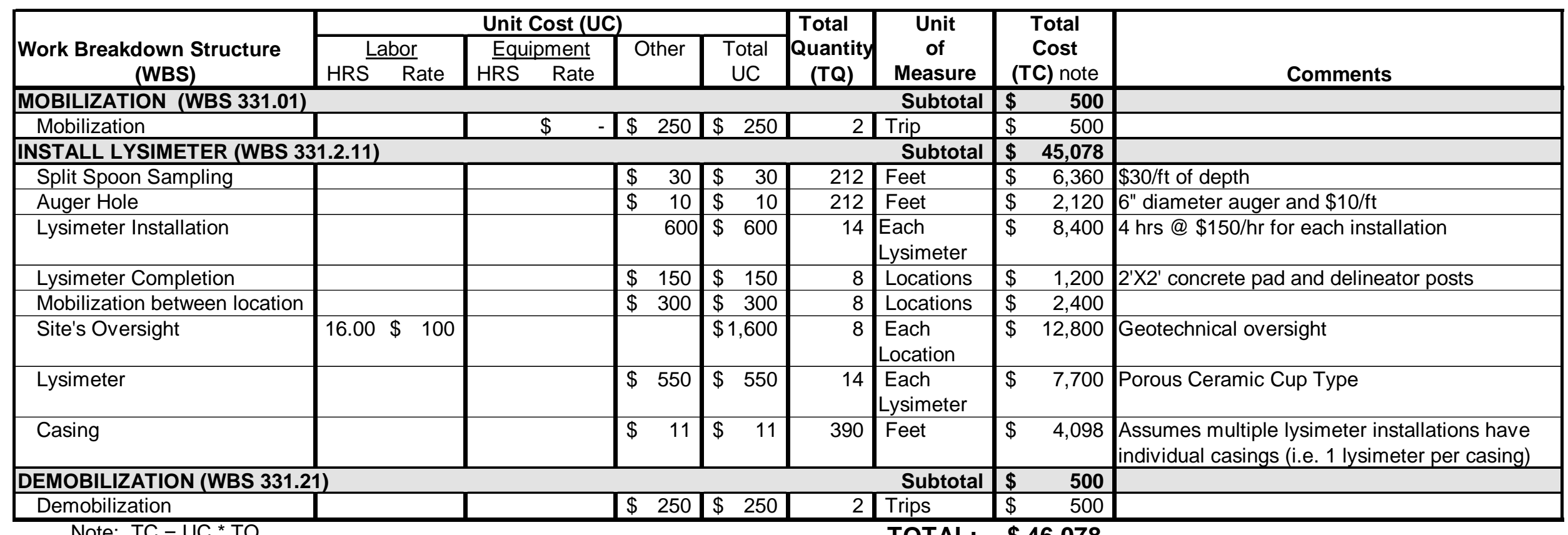




\section{ACRONYMS AND ABBREVIATIONS}

ANL Argonne National Laboratory

CMST-CP Characterization Monitoring and Sensor Technology Crosscutting Program

CPT

DOE

EM

FY

OST

$\mathrm{RCI}$

RCRA

SRS

TC

TQ

UC

WSRC Cone Penetrometer Truck

U. S. Department of Energy

DOE Environmental Management

Fiscal Year

Office of Science and Technology

Rapid Commercialization Initiative

Resource Conservation and Recovery Act

Savannah River Site

Total Cost

Total Quantity

Unit Cost

Westinghouse Savannah River Company 